\title{
Friction stir processing (FSP) and superplasticity
}

\author{
T.R. McNelley \\ TMcNelley@nps.edu
}

Department of Mechanical \& Aerospace Engineering, Naval Postgraduate School, Monterey, CA 93940, U.S. A.

FSP is an allied technology of friction stir welding (FSW). The development and applications of these technologies are reviewed and additional considerations such as processing pattern and step over distance between successive passes in FSP are discussed. The deformation field for a rotating and advancing tool is not symmetric about the axis of tool motion. Thus, various spiral patterns with step over distances less than the tool pin diameter result in replacement of advancing interfaces (tool tangential velocity and traversing speed add) retreating interfaces (tool tangential velocity and traversing speed subtract) and greater homogeneity of the resulting stir zone microstructures. Microstructures formed as a result FSP often exhibit refined and uniform distributions of non-deforming constituents as well as highly refined grain structures, and superplastic response following FSP of wrought 7XXX and 5XXX Al alloys has been achieved. The application of multi-pass FSP to cast metals, including continuously cast (CC) AA5083 and AA356 as well as a Na modified Al-7Si will be summarized and the conversion of as-cast microstructures to a wrought condition in the absence of external shape change will be shown. Grain refinement is the result of recrystallization during the rapid thermomechanical cycle of FSP. The mechanisms involved in homogenization of constituent particle distributions remains to be determined. The FSP-induced superplastic response of the AA5083 will be documented. In contrast, grain refinement in the Na modified Al-7Si alloy was insufficient to support superplasticity.

Keywords: friction stir processing, recrystallzation, grain refinement, micrsotructure homogenization, particle refinement, microstructure stability, superplasticity

\section{Обработка трением с перемешиванием (ОТП) и сверхпластичность}

Обработка трением с перемешиванием (ОТП) представляет собой технологию, родственную технологии сварки трением с перемешиванием (СТП). Дан обзор развития и применения этих технологий и обсуждены дополнительные вопросы, такие как схема обработки и длина шага по поверхности между последовательными проходами при ОТП. Поле деформации для вращающегося и движущегося поступательно инструмента несимметрично относительно направления движения инструмента. Поэтому различные спиральные схемы обработки с длиной шага менее диаметра наконечника инструмента приводят к замене интерфейсов движущейся вперед стороны (тангенциальная скорость инструмента и скорость поступательного движения складываются) интерфейсами движущейся назад стороны (тангенциальная скорость инструмента и скорость поступательного движения вычитаются) и к более высокой однородности микроструктуры зоны перемешивания. Микроструктуры, формируемые в результате ОТП, часто демонстрируют однородное распределение измельченных недеформируемых составляющих, а также сильно измельченную зеренную структуру, и после ОТП кованых алюминиевых сплавов 7XXX и 5XXX достигается сверхпластическое поведение. Обобщены данные о применении многопроходной ОТП к литым металлам, включая сплавы AA5083 и AA356, полученные непрерывным литьем, а также Al-7Si, модифицированный $\mathrm{Na}$, и показано преобразование литой микроструктуры в кованую без изменения внешней формы. Измельчение зерен является результатом рекристаллизации при быстром термомеханическом цикле ОТП. Механизмы, определяющие однородное распределение частиц, предстоит выяснить. Будет документировано сверхпластическое поведение сплава АA5083, вызванное ОТП. В противоположность, измельчение зерен в сплаве Al-7Si, модифицированном $\mathrm{Na}$, было недостаточно для достижения сверхпластичности.

Ключевые слова: обработка трением с перемешиванием, рекристаллизация, измельчение зерен, гомогенизация микроструктуры, измельчение частиц, стабильность микроструктуры, сверхпластичность 


\section{Introduction}

FSP is a solid-state deformation processing method involving the use of a non-consumable, rotating tool. Among the benefits of FSP are refinement and homogenization of microstructures in metallic materials [1,2]. It is an allied process of FSW, a solid-state joining method originally developed by The Welding Institute [3]. All FS technologies rely on a severe but localized thermomechanical cycle induced by tool action on a deformable material.

The initial motivation for the development of FSW was the desire to circumvent the problem of solidification cracking often encountered in fusion welding of many high-strength aluminum alloys [3]. FSW has been applied successfully to a wide range of $\mathrm{Al}, \mathrm{Mg}, \mathrm{Cu}, \mathrm{Fe}$ and $\mathrm{Ti}$ alloys. The basic concept of FSW is straightforward and this process has been extensively reviewed elsewhere; see, e.g., [1,2]. The work pieces to be joined are abutted and fixed against a rigid restraint that serves as an anvil. A cylindrical wear resistant tool consisting of a smaller diameter pin with a concentric, larger diameter shoulder is rotated while the pin is forced into the surfaces of the parts at a point along the abutment line.

A combination of frictional and adiabatic heating results in the formation of a plasticized column of metal and a localized 'stirring' action involving deformation and motion of material around the tool pin as it penetrates. After the tool shoulder comes in contact with the work piece surfaces the tool is traversed along the abutment line and the flow of material about the tool pin leads to coalescence across the faying surfaces and the formation of a weld. Single-pass, single-sided welds are readily produced by FSW. The pin length must be slightly less than the thickness of the joint so that the pin does not come in contact with the anvil. The tool shoulder provides control of the tool penetration. The shoulder also controls upward flow of metal and forges the weld nugget. Many tool design features have been evaluated, including pin shape and the presence of threads, flutes and stepped spirals on tapered pins. Critical process parameters include tool rpm and traversing rates. Aluminum materials of thicknesses varying from $<1 \mathrm{~mm}$ to $>25 \mathrm{~mm}$ have been joined by FSW and many variations on the basic concept of FSW have been reported in recent years [2].

\section{FSP of Metallic Materials}

A distinct but allied process, FSP involves a single work piece and the traversing of the tool in a predetermined pattern over the work piece surface thereby processing a volume of material, termed the stir zone (SZ), defined by the tool pin profile and the traversing pattern [4,5]. The full thickness may be processed but in many applications the pin length is less than the workpiece thickness so that only a surface layer is subjected to the FSP thermomechanical cycle. The depth of this layer is limited by tool design, available power and the capability of reacting and controlling the downward axial, or plunge, force needed to accomplish FSP. Such FS technology has been applied to as-cast as well as wrought metals including alloys of $\mathrm{Al}$ and $\mathrm{Mg}$ as well as higher melting alloys of $\mathrm{Cu}$, Fe and Ti [4]. Fig. 1 shows a schematic illustration of a FSP

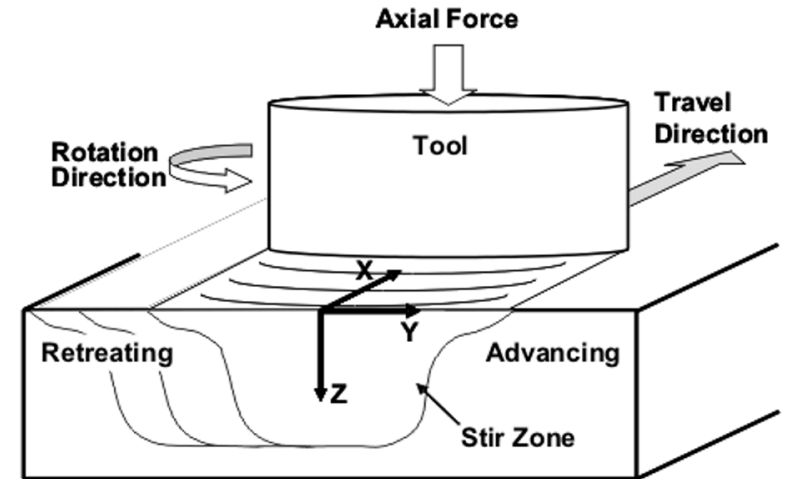

Fig. 1. A schematic of multi-pass FSP with overlapping passes. The tool pin is not visible in this representation.

pass in multi-pass processing wherein successive passes are offset from one another. Due to tool rotation the deformation field around the tool pin is not symmetric about the tool travel direction. Thus, there is often variation in microstructure from the advancing side (tool surface speed and traversing speed add) to the retreating side (tool surface speed and traversing speed subtract).

Additional important process parameters in FSP include the tool traversing pattern and the 'step over' distance between adjacent passes during multi-pass processing. These are illustrated in Fig. 2. The traversing pattern may consist of a single linear or curvilinear processing pass, Fig. 2a, or a series

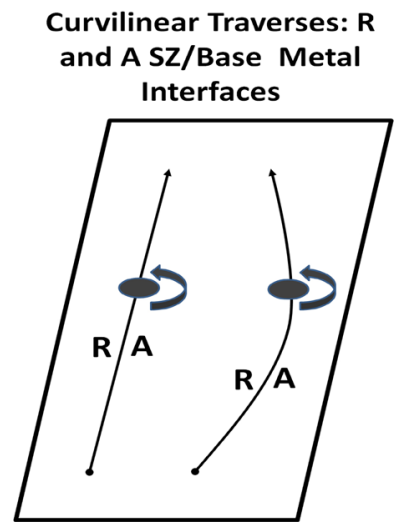

a

Raster Pattern: R/R/A/A /R/R Interfaces in Stir Zone

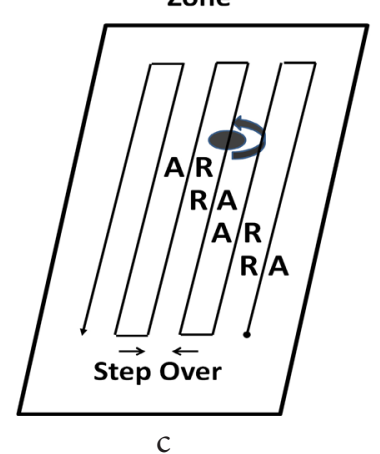

$A / R$ Interfaces in Stir Zone

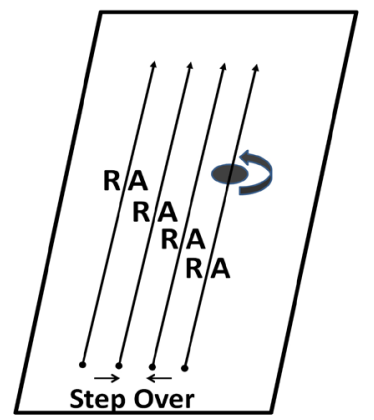

b

Spiral Patterns: A/R/A/R

Interfaces in Stir Zone (ex. Initial Pass)

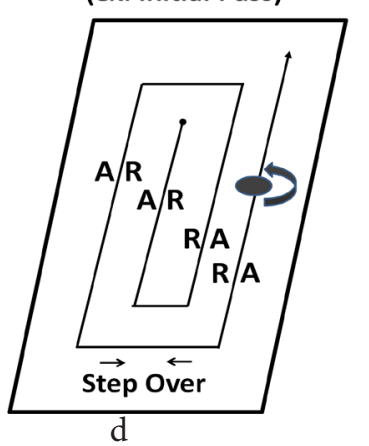

Parallel Traverses: A/R/

Fig. 2. Traversing patterns for FSP: a single linear or curvi-linear traverse (a); multi-pass FSP by a series of traverses offset by a step over in (b), a raster pattern in (c) or a spiral pattern in (d). 
of linear traverses offset by stepping over by a pre-determined distance as indicated in Fig. 2b. Microstructure gradients are typically more pronounced on the advancing side than on the retreating side. A series of parallel traverses as suggested in Fig. $2 b$ result in successive replacement of advancing interfaces with retreating interfaces in the processed volume of material. In contrast, a raster pattern as shown in Fig. 2c results in advancing/advancing and retreating/retreating interfaces in a direction transverse to the axis of tool advance during rastering. Accompanying long-range variations in microstructure may result in strain localization and reduced ductility. In contrast, a spiral pattern such as suggested in Fig. $2 \mathrm{~d}$ again results in replacement of advancing interfaces with retreating interfaces on successive passes and thus may mitigate gradients in SZ microstructure. In turn, resulting mechanical properties would be expected to be more nearly independent of direction within the plane of the processed sheet or plate.

The step over distance is typically based on the pin diameter in order to assure overlap of SZs on successive passes in multi-pass processing, as suggested in Fig. 1. The SZ is generally broader at the work piece surface due to the influence of the tool shoulder. An excessive step over distance may lead to incomplete overlap in lower regions of the SZ on successive passes and microstructure gradients accompanied by strain localization and reduced ductility. A complex as-cast NiAl Bronze material was processed using the spiral pattern of Fig. $2 \mathrm{~d}$ with a step over distance set at $1 / 2$ of the pin diameter at mid-length of a $12.7 \mathrm{~mm}$ long pin. A volume of $375 \mathrm{~cm}^{3}$ of SZ material was produced. Phase transformations during the FSP thermomechanical cycle resulted in refinement and homogenization of microstructure, and a dramatic increase in both strength and ductility as well as isotropic properties of SZ material [5-9].

\section{Achieving superplasticity by FSP}

Highly refined and homogeneous grain structures are characteristic of weld nugget and, especially, SZ microstructures of materials subjected to multi-pass FSP $[1,2]$. The phenomena involved in recrystallization have been studied mainly in materials subjected to approximately uniform strains under isothermal conditions [10]. FS technologies involve severe deformations but under conditions that involve rapid transients and steep gradients in strain, strain rate and temperature $[11,12]$. Nevertheless, many features of weld nugget and SZ microstructures can be accounted for in terms of our current understanding of recrystallization [10]. However, important details of the processes leading to formation of the highly refined grain structures observed in materials subjected to FSP remain to be clarified [13]. Indeed, grains 25-100 $\mathrm{nm}$ in size has been observed after tool plunge and extraction experiments on AA7050 [14].

Conventional deformation and recrystallization treatments have been developed to obtain superplastic sheet material in several Al alloys, including AA7475 [15] and AA5083 [16]. Typical recrystallized grain sizes are $8-10 \mu \mathrm{m}$ and subsequent peak ductility values of $400-500$ pct. at strain rates of $\approx 10^{-4} \mathrm{~s}^{-1}$ are apparently sufficient to support hot blow forming of components for engineering applications. After FSP of such alloys as well as AA7050 and the cast alloy AA356 superplastic ductilities exceeding 500 pct. at strain rates $>10^{-2} \mathrm{~s}^{-1}$ have been attained [17-28]. Grain sizes are typically $<5 \mu \mathrm{m}$ and thus finer than in conventionally processed material although the grain size depends strongly on FSP conditions. Constituent particles are often refined in size and more homogeneously distributed in FSP material when comparison is made to the conventionally processed counterpart material. This may account for a change in failure mode, from quasi-brittle fracture associated with cavity formation and growth associated with coarse constituent particles to diffuse necking and diminished cavity formation.

\section{An Example: FSP of Continuously Cast AA5083 in the As-Cast Condition}

The industrial processes of superplastic forming (SPF) and quick plastic forming (QPF) of AA5083 have been of interest for transportation applications [29]. Material produced by conventional direct-chill casting has been processed by a combination of hot and cold working so that recrystallization upon heating for subsequent QPF gives a grain size of $\approx 7 \mu \mathrm{m}$ and this is sufficient for good biaxial forming during SPF and QPF. The introduction of continuously cast (CC) AA5083 would help reduce costs but as-cast CC slab is typically only $15 \mathrm{~mm}$ in thickness and thus cannot be strained sufficiently during hot and cold working to homogenize as well as refine microstructure in the production of sheet material. Thus, subsequent ductility is marginal for SPF and QPF [30-32].

The potential of FSP to homogenize and refine microstructure suggests that its application to CC material be evaluated to determine whether the resulting microstructures exhibit improved superplastic response. The CC AA5083 material was in the form of $15 \mathrm{~mm}$ thick slab and further details have been given previously $[30,32]$. Composition data are given in Table 1.

A plate for FSP was sectioned from the as-cast CC material and surfaces were machined prior to processing. FSP was conducted using tools fabricated in H13 hot-work die steel and heat treated to HRC52. The tools had a shoulder diameter of $10 \mathrm{~mm}$, the tool pins were $3 \mathrm{~mm}$ in diameter, $5 \mathrm{~mm}$ in length, and the design included a thread feature. A tool is shown in Fig. 3a. The FSP involved three overlapping passes as illustrated in Figs. $2 \mathrm{~b}$ and $3 \mathrm{~b}$, with a tool rotation rate of $350 \mathrm{rpm}$ and traversing rate of $101.6 \mathrm{~mm} \mathrm{~min}^{-1}$ (experiment 1) or $800 \mathrm{rpm}$ and traversing rate of $76.2 \mathrm{~mm}$ $\mathrm{min}^{-1}$ (experiment 2 ). In both cases the step over distance was $2 \mathrm{~mm}$ to assure complete overlap of the SZs.

The heat input during FSP corresponds very approximately to the ratio of rotation rate to traversing rate and so the SZ for

Table 1. Composition of the CC AA5083

\begin{tabular}{llllllll}
\hline $\begin{array}{l}\text { Ele }- \\
\text { ment }\end{array}$ & $\mathrm{Mg}$ & $\mathrm{Mn}$ & $\mathrm{Si}$ & $\mathrm{Fe}$ & $\mathrm{Cr}$ & $\mathrm{Cu}$ & $\mathrm{Zr}$ \\
\hline $\begin{array}{l}\text { Wt. } \\
\text { Pct. }\end{array}$ & 4.62 & 0.74 & 0.10 & 0.19 & 0.25 & 0.02 & 0.001 \\
\hline
\end{tabular}




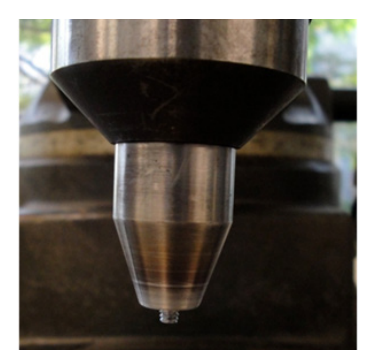

a

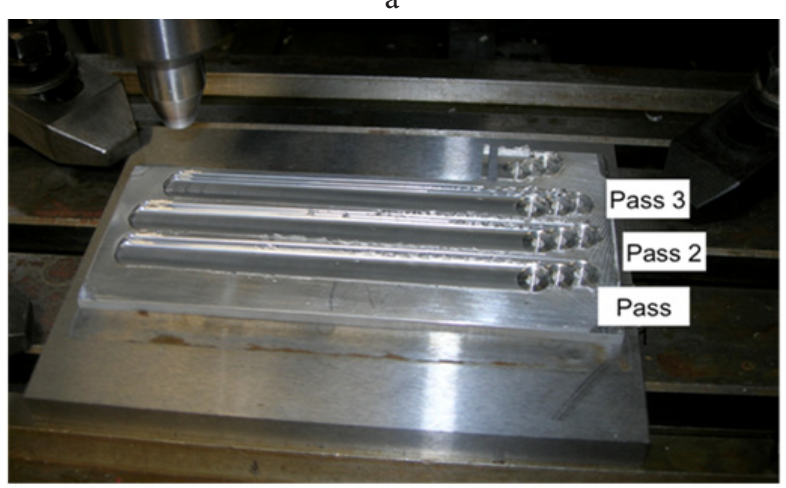

Processed Plate

b

Fig.3. Photograph of the FSP tool in (a) and of a processed CC AA5083 plate (b) showing three runs each involving three overlapping passes as illustrated in Fig. 2b.

the material of experiment 2 should reflect more prolonged heating and a slower cooling rate than that of experiment 1. Further details of the methods of microstructure analysis have been given previously [16].

The homogenization as well as refinement of microstructure that may be attained during FSP of this material is illustrated in the optical micrographs in Fig. 4. The microstructure of the unaffected base metal is shown in Fig. 4a from a location distant from the SZ. The as-cast grain size in the primary a constituent appears to be equiaxed and $\approx 50 \mu \mathrm{m}$ in size. The dark-etching constituent is a eutectic comprising mainly the $\beta$-phase $\left(\mathrm{Al}_{8} \mathrm{Mg}_{5}\right)$ and dispersed particles of the $\mathrm{MnAl}_{6}$ phase may also be discerned. Careful examination of the primary constituent in this micrograph reveals contrast variation suggesting cellular or dendritic growth during solidification. Extensive refinement as well as homogenization of microstructure constituents is evident in Fig. 4 b, which is a micrograph from the SZ of material processed at $350 \mathrm{rpm}$ and $101.6 \mathrm{~mm} \mathrm{~min}^{-1}$. The grain size in the a phase cannot be discerned at the magnification in this image, and the primary $a$ and eutectic constituents observed in the as-cast material are no longer distinguishable. Indeed, the eutectic $\beta$ phase has been substantially refined in size and the resulting particles redistributed uniformly in the microstructure. The $\mathrm{MnAl}_{6}$ particles have also been redistributed. It is especially noteworthy that no cavities or other features that might be associated with cracking of particles are apparent in this image. The absence of residual damage in the microstructure likely reflects the development of a hydrostatic component in the stress state within the SZ due to the compressive axial force on the tool was well as constraint by cooler surrounding material on the hot, deforming material in the SZ.

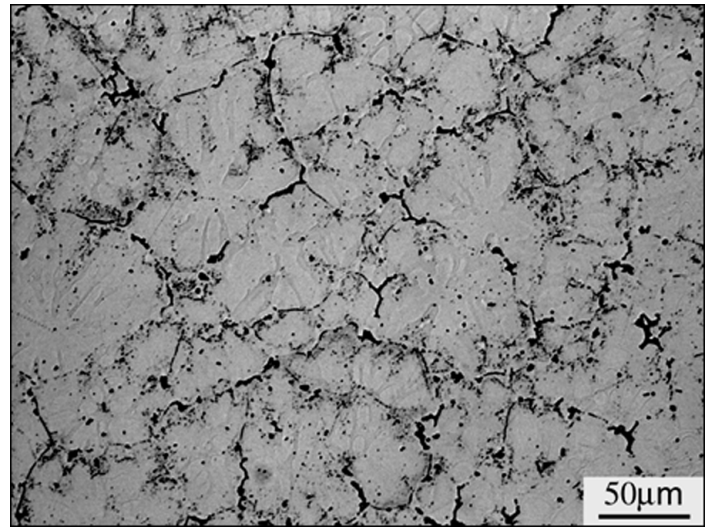

a

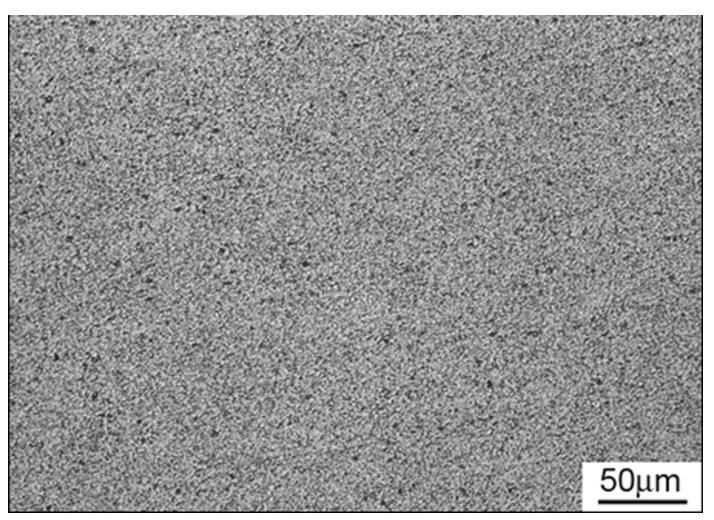

b

Fig. 4. The as-cast material is shown in (a) and homogenization and refinement due to FSP at $350 \mathrm{rpm}$ and $101.6 \mathrm{~mm} \mathrm{~min}^{-1}$ are illustrated in (b).

A highly refined stir zone grain size is apparent in the backscatter electron image of Fig. 5a. The $\beta$ phase particles (dark in appearance) are apparently submicron in size and are often distributed on the grain boundaries of the a phase grains. In some locations, the $\beta$ particles form a necklace-like structure on these grain boundaries. In contrast, the $\mathrm{MnAl}_{6}$ particles (light in appearance) are more or less uniformly distributed in the matrix and most of these particles are submicron in size. However, several large particles, $0.5-2.0 \mu \mathrm{m}$ in size, are also apparent in this image. Highly refined grains are also apparent in the STEM image in Fig. $5 \mathrm{~b}$ and fringe patterns at some boundaries suggest that high-angle boundaries surround grains as fine as $300 \mathrm{~nm}$ in size. Finely dispersed particles $10-100 \mathrm{~nm}$ in size are also distributed throughout the microstructure.

Grain sizes for both processing experiments were obtained by use of OIM methods. The results of OIM analysis are summarized in Fig. 6a for the material of experiment 1 (FSP at $350 \mathrm{rpm}$ and $101.6 \mathrm{~mm} \mathrm{~min}^{-1}$ ) and in Fig. 6b for the material of experiment 2 (FSP at $800 \mathrm{rpm}$ and $76.2 \mathrm{~mm}$ $\mathrm{min}^{-1}$ ). The mean linear intercept grain size in Fig. $6 \mathrm{a}$ for the material of experiment 1 was determined to be $1.2 \mu \mathrm{m}$ while that in Fig. $6 \mathrm{~b}$ for the material of experiment 2 was $3.5 \mu \mathrm{m}$. Grain-to-grain misorientations include a population of low-angle $\left(0-5^{\circ}\right.$ misorientation) boundaries in otherwise random distributions exhibiting peaks at $\approx 45^{\circ}$ in both cases. 

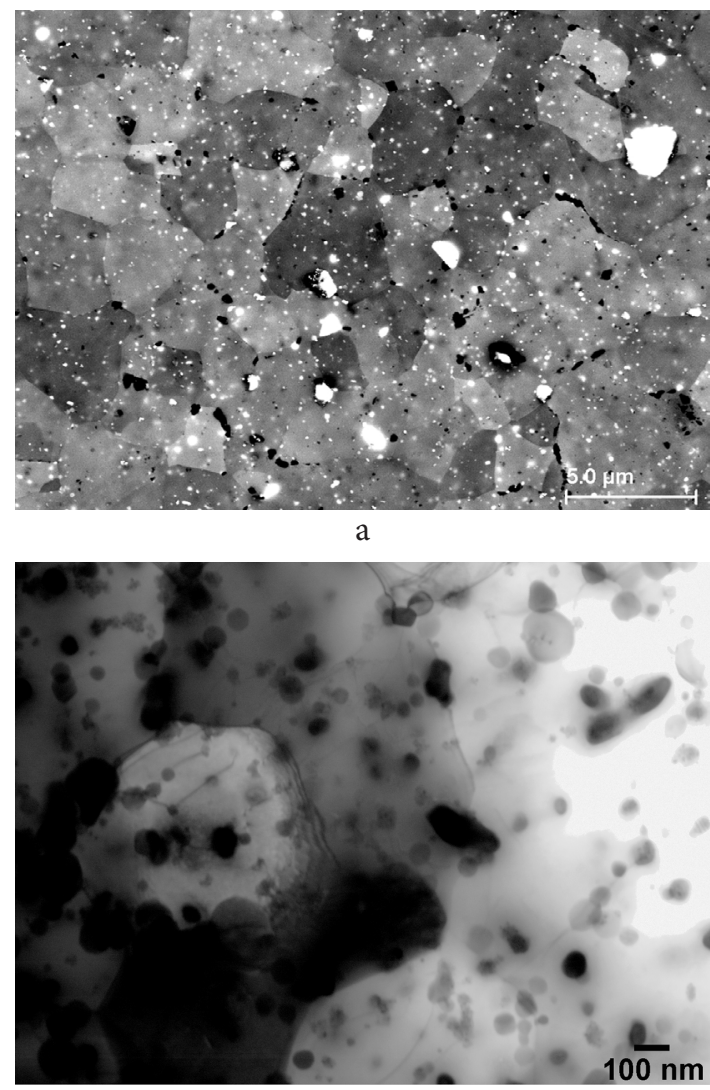

b

Fig. 5. A backscatter electron image shows refined grains $\approx 2 \mu \mathrm{m}$ in size in (a) and a STEM image in (b) shows highly refined $\beta$ phase and $\mathrm{MnAl}_{6}$ constituent particles.

The texture appears to be random in Fig. 6a while a weak B-type shear texture component appears to have formed and been retained in the material processed during experiment 2 .

The results of the microstructure analysis here show that highly refined grains approaching $1.0 \mu \mathrm{m}$ in size may be attained during FSP of the as-cast material. In contrast, grain sizes of $7-8 \mu \mathrm{m}$ were reported for both direct-chill and continuously-cast AA5083 materials after conventional hot and cold rolling followed by reheating and recrystallization prior to forming. In order to assess the potential for superplastic response of the FSP materials a series of tension tests were conducted on SZ samples for both processing experiments. Tensile samples were obtained by wire electro discharge machining (EDM) in order to assure that the gage sections were completely within the SZs. Light grinding of the samples was carried out to assure removal of any recast layers produced by EDM. The samples were then pulled to failure at constant crosshead speeds corresponding to various strain rates and at a test temperature of $450^{\circ} \mathrm{C}$.

The results of these tests are presented in Fig. $7 \mathrm{a}$ as the flow stress at a strain of 0.1 as a function of strain rate, and in Fig. $7 \mathrm{~b}$ as the corresponding ductility as a function of strain rate. The data for the two FSP experiments are shown as solid lines while data for conventionally rolled DC or CC materials are shown as dotted curves. The data in Fig. 7a shows that grain refinement by FSP dramatically reduces the flow stress. For example, at a stain rate of $2 \times 10^{-2} \mathrm{~s}^{-1}$ the flow stress of the material processed in experiment 1 , denoted as Ex 1 in Fig. $7 \mathrm{a}$, is lower by a factor of six when compared to the
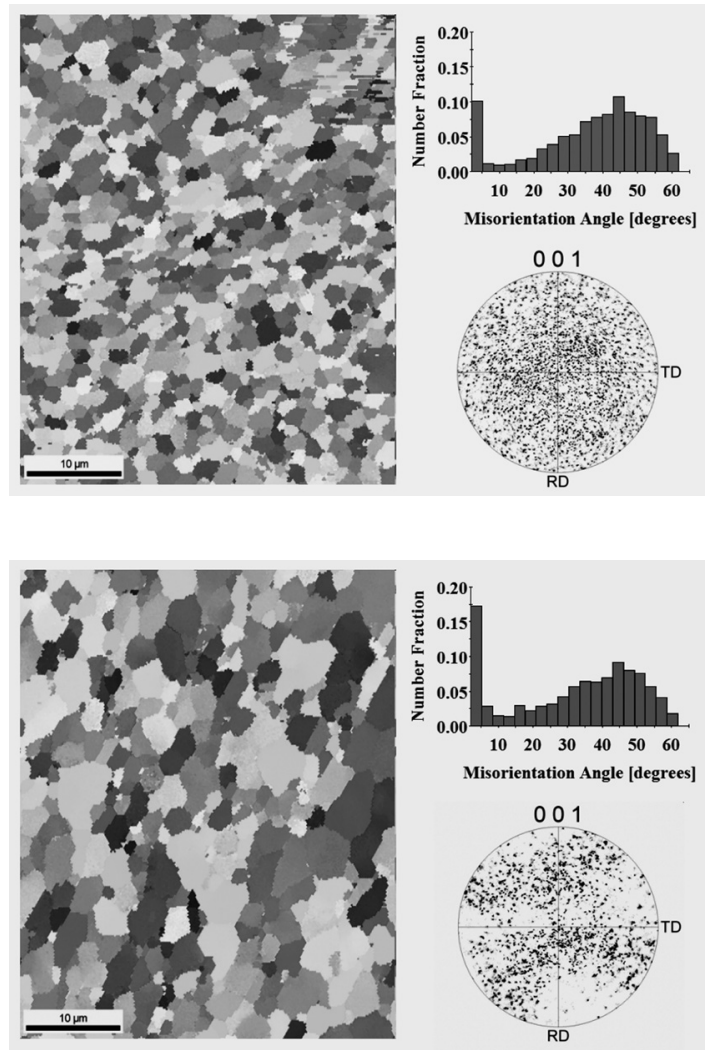

Fig. 6. OIM data showing refinement of grains to $\approx 1.2 \mu \mathrm{m}$ in size for experiment 1 material and $\approx 3.5 \mu \mathrm{m}$ in experiment 2 material. Near random texture and misorientation distribution is apparent in (a) while a weak B-type shear texture is evident in (b).

same CC material in a conventionally processed condition. The flow stress versus strain rate relationship for superplastic materials deformed at a constant temperature is often characterized by the power law relationship $\sigma=K \varepsilon^{\prime} m$, where $\sigma$ is the flow stress, $K$ is a material constant and $\dot{\varepsilon}$ is the strain rate and $m$ is the strain rate sensitivity coefficient. Here, it is apparent that grain size refinement leads to an increase in the strain rate sensitivity such that $m \rightarrow 0.5$ for the finest grain size material. Such an $m$ - value is consistent with the ductility of 1,200 pct. at a strain rate of $10^{-1} \mathrm{~s}^{-1}$, which is the strain rate for maximum $m$.

It is noteworthy that the flow stress at this strain rate of 10 pct. per second is equal only to that of conventionally processed CC material at a strain rate that is 100 times lower! The ductility achieved here by FSP of this commercially produced AA5083 material appears to be the highest superplastic ductility reported for this alloy. The material processed during experiment 2 and denoted as Ex. 2 in Fig. 7, has a grain size of $\approx 3.5 \mu \mathrm{m}$, a value intermediate to that of Ex 1 material and the conventionally rolled CC material, and the corresponding flow stress and ductility data are likewise intermediate to those of Ex 1 material and the conventionally rolled CC material. Finally, the enhancement of superplastic ductility by FSP reflects two factors. These are the increase in the strain rate sensitivity coefficient, $m$, through grain size refinement, and the suppression of cavity formation through refinement of the eutectic $\beta$ phase as well as the $\mathrm{MnAl}_{6}$ constituent particles. 


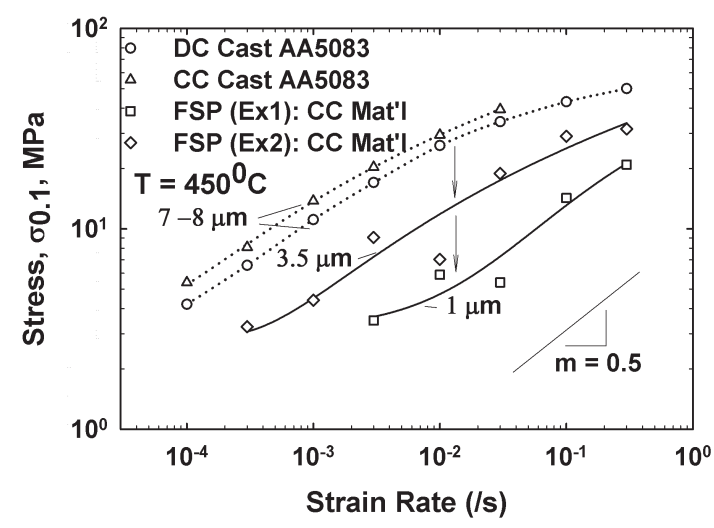

a

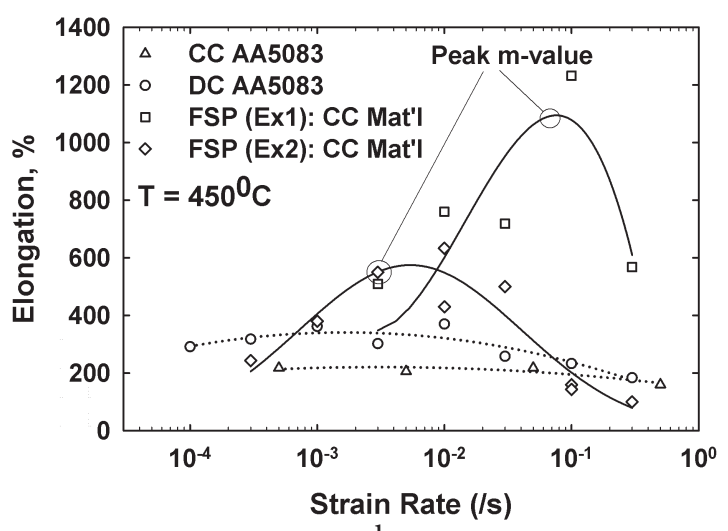

$\mathrm{b}$

Fig. 7. Mechanical property data for AA5083 material as flow stress as a function of strain rate in (a) and ductility as a function of strain rate in (b) for CC material processed by FSP (solid lines) and both conventionally processed direct-chill cast and continuously cast materials.

\section{Summary and conclusions}

1. FSP is an allied process of FSW and may be applied to a wide range of metallic materials to achieve refinement and homogenization of microstructure.

2. Either wrought or cast metals may be processed by FSP.

3. Consideration must be given to processing parameters that include tool pin length relative to material thickness, tool traversing pattern, and 'step over' distance in multi-pass processing.

4. Superplasticity has been achieve by FSP in a wide variety of engineering alloys, including high-strength Aluminum materials, as-cast Aluminum alloys and materials in other alloy systems.

5. FSP may be applied to only selected regions in order to achieve enhanced superplastic ductility in localized areas of components.

6. Grain size is dramatically refined by recrystallization during FSP of as-cast CC AA5083 material. Constituent particles are also refined and redistributed uniformly although the mechanism (s) involved in refinement and redistribution remain to be determined.

7. Enhanced superplastic response was attained in CC AA5083 processed by FSP and an elongation exceeding $1,200 \mathrm{pct}$. was attained at a strain rate of $10^{-1} \mathrm{~s}^{-1}$ during testing at $450^{\circ} \mathrm{C}$.
8. Altogether, these results demonstrate the potential for enhancement of superplasticity in commercial alloys when constituent particles are refined and their distribution homogenized as well as by grain size refinement.

Acknowledgements. This work was supported in part by the University of Texas - Austin and General Motors Corporation, as well as by the US Office of Naval Research.

\section{References}

1. R. S. Mishra and Z. Y. Ma, Mater. Sci. Eng. R 50, 1 (2005).

2. Friction Stir Welding and Processing, ASM International, R.S. Mishra and M.W. Mahoney, Eds., Materials Park, $\mathrm{OH}$ (2007).

3. W.M. Thomas, et al., G.B. Patent Application No. 9125978.8, 1991; U. S. Patent No. 5460317, 1991.

4. R.S. Mishra, in Friction Stir Welding and Processing. ASM International, R.S. Mishra and M.W. Mahoney, Eds., Materials Park, OH. 309 (2007).

5. T. R. McNelley, K. Oh-Ishi and A. P. Zhilyaev, in Friction Stir Welding and Processing. ASM International, R.S. Mishra and M.W. Mahoney, Eds., Materials Park, OH. 155 (2007).

6. K. Oh-Ishi and T.R. McNelley, Metall. Mater. Trans. A, 35, 2951 (2004).

7. K. Oh-Ishi and T.R. McNelley, Metall. Mater. Trans. A, 36, 1575 (2005).

8. K. Oh-Ishi, A.P. Zhilyaev and T.R. McNelley, Metall. Mater. Trans. A, 37, 2239 (2006).

9. S. Swaminathan, et al., Metall. Mater. Trans. A, 41, 631 (2010).

10. R. D. Doherty, et al., Mater. Sci. Eng. A 238, 219 (1997).

11. A. Askari, S. Silling, B. London, M.W. Mahoney, in Friction Stir Welding and Processing, K. V. Jata, et al., Eds., TMS, Warrendale, PA, 43 (2001).

12. D. P. Field, T. W. Nelson, Y. Hovanski, K. V. Jata, Metall. Mater. Trans. A, 32, 2869 (2001).

13. T. R. McNelley, S. Swaminathan and J. Q. Su, Scri. Mater., 58, 349 (2008).

14. J. Q. Su, T. W. Nelson and C. J. Sterling, J. Mater. Res., 18, 1757 (2003).

15. J. A. Wert, N. E. Paton, C. H. Hamilton and M. W. Mahoney, Metall. Trans. A, 12A, 1265 (181).

16. T. R. McNelley, et al., Metall. Mater. Trans. A, 39, 50 (2008)

17. R. S Mishra, et al., Scri. Mater., 42, 163 (2000).

18. R.S. Mishra and M.E. Mahoney, Mater. Sci. Forum, 357-359, 507 (2001).

19. M.W. Mahoney, R.S. Mishra and T.W. Nelson, in Proceedings of the 3rd Int'l Symp. On Friction Stir Welding, JWS, Kobe, Japan, (2001).

20. M.W. Mahoney, et al., in Friction Stir Welding and Processing, K. V. Jata, et al., Eds., TMS, Warrendale, PA, 183 (2001).

21. M. W. Mahoney, R. S. Mishra and T. W. Nelson, Industrial Heating, 31 (February, 2002).

22. Z.Y. Ma, R.S. Mishra, M.W. Mahoney and R. Grimes, Acta Mater., 50, 4419 (2002).

23. Z. Y. Ma, R.S. Mishra, M. W. Mahoney and R. Grimes, 
Mater. Sci. Eng., A351, 148 (2003).

24. M. W. Mahoney, A. J. Barnes, W.H. Bingel and C. Fuller, in Proceedings of the International Conference on Superplasticity in Advanced Materials, IOM3, Oxford, U. K. (2003).

25. Z. Y. Ma, R. Mishra and M. W. Mahoney, Scri. Mater., 50, 931 (2004).

26. M.W. Mahoney, R.S. Mishra, T.W. Nelson and A. J. Barnes, in Proceedings of LiMAT-2003, W. E. Frazier, Y.D. Han, N.J. Kim and E.W. Lee, Eds., Center for Advanced Materials, POSTECH, Korea (2004).
27. Z. Y. Ma, R.S. Mishra, M.W. Mahoney and R. Grimes, Metall. Mater. Trans. A, 35, 1951 (2004).

28. M. W. Mahoney, A. J. Barnes, W.H. Bingel and C. Fuller, Mater. Sci. Forum, 447-448, 505 (2004).

29. J. G. Shroth, in Proceedings of Advances in Superplasticity and Superplastic Forming, E.M. Taleff, et al., Eds., TMS, Warrendale, PA, 9 (2004).

30. M.A. Kulas, et al., Metall. Mater. Trans. A, 36, 1249 (2005).

31. M. A. Kulas, et al., Metall. Mater. Trans. A, 37, 645 (2006).

32. W. P. Green, et al., Metall. Mater. Trans. A, 37, 2727 (2006). 